\title{
Introduction to the forum:
}

\section{Wartime globalization in Asia, 1937-1945, conflicted connections and convergences}

Given war's propensity for trampling over and demolishing borders - its literal, one might even say primordial function as a motor of deterritorialization and reterritorialization ${ }^{1}-$ the scant scholarly attention paid it as a globalizing force remains surprising. An extensive body of literature has responded to the complex role of globalization in the making, as well as the supposed un-making, of conflict. Liberal economists and political theorists, in an intellectual lineage that dates back to the writings of the European Enlightenment, have come up with bold claims about economic integration and the emergence of a 'capitalist peace' ${ }^{2}$ Critics of their arguments have pointed to the European imperial violence which from the mid- $18^{\text {th }}$ century cleared the ground (and perhaps more importantly the seas) to make way for the so-called 'free' market world economy, and in the process established several of those fundamental global

\footnotetext{
${ }^{1}$ A. Appadurai, 'Disjuncture and difference in the global cultural economy'. Theory, Culture \& Society, vol. 7, 1990, pp. 295-310; idem, Modernity at large: cultural dimensions of globalization, $8^{\text {th }}$ print, University of Minnesota Press, Minneapolis, 2008.

2 E. Weede, 'Globalization: creative destruction and the prospect of capitalist peace' in Globalization and armed conflict, Schneider, G., Barbieri, K and Gleditsch N. P. (eds), Rowman and Littlefield Publishers, Lanham, Maryland, 2003, pp. 311-324. Also see Weede's 'The diffusion of prosperity and peace through globalization'. The Independent Review, vol. 9, no. 2, 2004, pp. 165-186; T. L. Friedman, The lexus and the olive tree: understanding globalization, rev. ed., Anchor Books, New York, 2000; F. Fukuyama, The end of history and the last man, Avon Books, New York, 1992.
} 
inequalities which have been perpetuated down to this day. ${ }^{3}$ The hard evidence of a more recent past makes a mockery of the earlier presumption that international capitalist enterprises such as Starbucks and McDonalds might bring about some kind of Big Mac and Frappucinomediated universal fraternity. ${ }^{4}$ Critical observers of globalization during the 'noughties' (20002010) now recognize it as being both one of the most interconnected decades in world history and also one of the bloodiest. ${ }^{5}$

However, the idea that wars, and in particular the twentieth century's two World Wars, in themselves produced distinct forms of intensified globalization (just as they disrupted and demolished pre-existing forms) has yet to find its place in a field largely characterised, as one scholar has put it, by its 'pacific tendencies' ${ }^{6}$ Historians, especially, have remained quiet on the matter, even as more of them take up a self-consciously global perspective in their work. There is no doubt that the study of the two World Wars has in one sense gone global. Important work has now established how far the military and civilian experiences of the First stretched out beyond Europe and the United States; it has advanced the view that the origins of the Second can be found in the stresses and strains of the 'global food economy'. At the same time, the discipline of history in general has yet to grapple with what David Bell, in a critical

\footnotetext{
${ }^{3}$ T. Barkawi, 'Connection and constitution: locating war and culture in globalization studies'. Globalizations, vol. 1 , no. 2, 2004, pp. 155-170.

${ }^{4}$ J. Grey, False dawn: the delusions of global capitalism, The New Press, New York, 1998.

${ }^{5}$ P. van Houwelingen, 'Walls, war and globalization: editorial for the special issue: globalisation and war'. Journal of Critical Globalisation Studies, vol. 2, 2010, pp. 4-10.

${ }^{6}$ T. Barkawi, 'Connection and constitution', p. 156.

${ }^{7}$ L. Collingham, The taste of war: World War Two and the battle for food, Allen Lane, London, 2011.
} 
review, labels the 'most direct form of "global connection" imaginable' - that is, 'military conquest' ${ }^{8}$

Students coming to the history of nineteenth and twentieth century globalization might therefore be forgiven for imagining that it was in fact what happened before and in between major international conflicts - that globalization was a process historically bookended by these conflicts; and confined to periods of, by comparison, relative 'capitalist peace', until the moment when it sprang forth rejuvenated following the thawing of the Cold War. Alternatively, from their reading of $A$ World Connecting, the recent mammoth volume of which Bell has been critical, these same students might adduce, as he puts it, that 'even the World Wars actually did surprisingly little to disrupt the long-term growth of global connections and networking ${ }^{9}-$ that, in effect, the onward forces of globalization carried on regardless in spite of such cataclysmic disruption. $^{10}$

The articles presented here, all of which focus on the globalizing impact of the 1937-1945 conflict in Asia, do not pursue this latter thesis. All our contributors implicitly recognize the

\footnotetext{
${ }^{8}$ D. A. Bell, 'This is what happens when historians overuse the idea of the network', in New Republic, vol. 25,
} October 2013, http://www.newrepublic.com/article/114709/world-connecting-reviewed-historians-overusenetwork-metaphor, [accessed, 1 November 2014].

${ }^{9}$ Ibid. See furthermore, Emily Rosenberg (ed), A history of the world: a world connecting, 1870-1945, Harvard University Press, Cambridge, Massachusetts, 2012.

${ }^{10}$ Recent research has seen more focus on wartime globalization during World War One in parts of the globe less directly affected by the battles, especially works which have looked at the globalization of radical anticolonial networks. See M. Ramnath, Haj to utopia: how the Ghadar movement chartered global radicalism and attempted to overthrow the British Empire, University of California Press, Berkeley, 2011; T. Harper, 'Singapore, 1915, and the birth of the Asian underground'. Modern Asian Studies, vol. 47, no. 6, 2013, pp. 1782-1811; H. Streets-Salter, 'The local was global: the Singapore Mutiny of 1915'. Journal of World History, vol. 24, no. 3, 2013, pp. 539576. 
major international conflicts of the twentieth century as unprecedented points of historical rupture and critical junctures in the history of the region's social, political, and economic transformation. They also appreciate that just as one might begin to write a history of global wartime convergences and connections, an equally valid enterprise would be to write the history of global wartime displacements, as the historian Sandra Barkhof and literature specialist Angel K. Smith have recently provided. Both these authors depict the twentieth century's World Wars as having unleashed worldwide processes of disconnection and alienation, as soldiers and civilians were forcibly dispersed to places far away from home and nation. $^{11}$

What our contributions do seek to provide, by exploring the forms of global convergence and connection which sprang from a specific wartime context, is a more nuanced appreciation of the nature of these ruptures. Each article, in its own distinct way, explores the intensified traffic of people, information, ideologies, aid, and even political performance, for which the war of 1937-1945 in Asia, notwithstanding the chaos and destruction it wrought, was directly responsible. As a whole, this forum expands on the arguments made by Tarak Barkawi who, in his study of the mobilization and transportation of the British Indian Army, and of the United States Army's more recent campaigns in Vietnam and Iraq, sought to depict the way in which war 'constituted' new global connections. ${ }^{12}$

But this forum also raises the question of whether such wartime connections - which typically developed rapidly, and were more often than not fragile, punctuated, and temporary - can be adequately conceptualized through our current language of globalization. This language has long been anchored in notions of webs, flows, circuits and circulations which

\footnotetext{
${ }^{11}$ S. Barkhof and A. K. Smith, War and displacement in the twentieth century: global conflicts, Routledge, London, 2014, See, in particular, the introduction, pp. 1-18.

12 T. Barkawi, 'Connection and constitution'.
} 
assume some degree of permanence through the longer-term social, economic, and political processes which produce them. In the violent and haphazard context of world war, however, when migration was frequently one-way and coerced, the 'flow' of information censored, and vital circuits and circulations cut, is such a language still appropriate? Do we instead need to distinguish the emergence of a more intense, frenetic and un-structured globalization, as the points at either end of the lines of communication shifted from location to location, in frantic manoeuvers designed to re-establish essential routes of supply? It is hoped that some of the articles in this forum make the case for answering this question, in certain cases, in the affirmative.

\section{A global history of the war in Asia: framing the regional}

Why focus specifically on Asia during the Second World War? The articles in this forum examine a region and a period where it might fairly be observed that much has already been done to highlight border-crossing connections, without this research having explicitly defined itself as part of a wider history of globalization effort. Chris Bayly and Tim Harper's pivotal two-volume history of the war in British Asia and its aftermath purports, from its opening chapter, to trace the connections that ran along what they have termed the 'great crescent' linking India with Burma, Malaya, and Singapore. Especially in their first instalment, which has chronicled the 'forgotten armies' that moved across this arena, they provide the first attempt at a coherent transnational account of the interconnected experience of World War Two across these territories. ${ }^{13}$ Our understanding of the massive regional movements of Asian civilians during this conflict owes much to the research of historians such as Sunil Amrith, who has

\footnotetext{
${ }^{13}$ C. A. Bayly and T. Harper, Forgotten armies: the fall of British Asia, 1941-1945, Harvard University Press, Cambridge, Massachusetts, 2006.
} 
addressed Indian migration between Southeast and South Asia, and Paul Kratoska, who has edited an important volume on labour migration within Japan's wartime empire. ${ }^{14}$ Tracing another form of wartime mobility, Ernest Koh has recovered the engagement of overseas Chinese of Singapore with China during the Second Sino-Japanese War, which culminated in their contributions - of funds, machinery and personnel - to the 'Burma Road' from Lashio to Kunming, a new supply line intended to relieve China's nationalist forces. ${ }^{15}$

Nonetheless, these works, in their willingness to surmount the boundaries by which other works abide, remain striking exceptions. Undoubtedly, major studies of World War Two in Asia have now begun to at last 'globalise' the study of a subject long defined by its pervasive Eurocentricism. ${ }^{16}$ In the process, these works have raised historiographical questions about the conflict's origins and its temporal identity. For the most part, however, they still take the nation-state as their principal framework of analysis, or, if they venture beyond it, adopt a lens circumscribed by the boundaries of modern area studies. ${ }^{17}$ The effect has been to drive a

${ }^{14}$ S. Amrith, Migration and diaspora in modern Asia, Cambridge University Press, Cambridge, $2011 ;$ P. H. Kratoska, Asian labour in the wartime Japanese empire: unknown histories, M. E. Sharpe, Armonk, 2005.

${ }^{15}$ E. Koh, Diaspora at war: the Chinese of Singapore between Empire and Nation, 1937-1945, Brill, Leiden, 2013. See also C. Twomey and E. Koh (eds), The Pacific War: aftermaths, remembrance and culture, Routledge, Abingdon, 2015.

${ }^{16} \mathrm{H}$. Liebau et al. (eds), The world in World Wars: experiences, perceptions and perspectives from Africa and Asia, Brill, Leiden, 2010.

${ }^{17}$ For China, see, for example: R. Mitter, China's war with Japan, 1937-1945: the struggle for survival, Penguin, London, 2013; D. Lary, The Chinese people at war: human suffering and social transformation, $1937-$ 1945, Cambridge University Press, Cambridge, 2010; S. R. MacKinnon, D. Lary and E. F. Vogel (eds), China at war: regions of China, 1937-1945, Stanford University Press, Stanford, 2007; D. Lary and S. R. MacKinnon (eds), Scars of war: The impact of warfare on modern China, UBC Press, Vancouver, 2001. Even superior works, such as MacKinnon's on wartime Wuhan, include only the briefest of analyses of the 
conceptual wedge through the northern, southern, and eastern parts of war-torn Asia, which the conflict did not itself necessarily generate, one which ignores the historical experience of wartime globalization which spilled across these imaginary divides.

This limitation is especially evident in the body of literature devoted to Japan's wartime Asian empire. For some decades, historians have regarded Japan's Southeast and Northeast Asian colonial territories as discrete and distinct spheres, in an apparent reinforcement of the earlier administrative logic of Tokyo's imperial officials. Duus, Myer, and Peattie's Japan's Wartime Empire, 1931-45 has at least moved things forward from the original volume in the series, which 'set aside' Southeast Asia as a separate imperial arena that was deserving of study in its own right. Yet, this latest offering still conforms to an area studies structure while it strives to provide a broader historical coverage. Japan's Nanyo annexations are examined in a separate section which follows one devoted to Japan's Northeast Asian empire, with the result that the possibility for new understandings about the integrated and interrelated history of these administrative units is nullified. ${ }^{18}$ Other studies likewise underline a degree of Southeast Asian exceptionalism in the history of the Japanese Empire, at the expense of a discussion of the connections which embedded it within a common imperial edifice. ${ }^{19}$ One notable exception is

transnational links and significance of the city. See S. R. MacKinnon, Wuhan, 1938: war, refugees, and the making of modern China, University of California Press, Berkeley, 2008.

${ }^{18}$ R. H. Myers and M. R. Peattie, The Japanese colonial empire, 1895-1945, Princeton University Press, Princeton, 1984. See in particular Preface, p. 9 on the decision of the editors to 'set aside' Southeast Asia; P. Duus et al., The Japanese wartime empire, 1931-45, Princeton University Press, Princeton, 2010; K. Hack and T. Rettig (eds), Colonial armies in Southeast Asia, Routledge, London, 2006.

${ }^{19}$ K. Goto, Tensions of empire: Japan and Southeast Asia in the colonial and postcolonial world, Ohio University Press, Athens, Ohio, 2003. Literary wartime circulations brought about by the 1937-45 conflict are considered by K. L. Thornber, Empire of texts in motion: Chinese, Korean, and Taiwanese transculturations of 
Kratoska's aforementioned edited volume on wartime labour. Another is Michael Baskett's study of transnational film culture in imperial Japan. This latter work paves the way for future efforts by arguing for the creation of a 'mass audience linked together by filmic discourses' in which film representations and their circulation became official tools of Japan's project of 'panAsianism' ${ }^{20}$

Of course, writing a history of wartime globalization in Asia is no simple task. Basic challenges of scale, expertise, and language proficiency readily explain the geographical frames which have been applied in existing historical enquiries. Moving beyond these frames demands a familiarity with an often overwhelming collection of distinctive political, social, and economic contexts. It frequently requires the integration of a degree of interdisciplinary and specialist area knowledge that is only achievable through scholarly collaboration. By the same token, it is hardly a given that every form of border-crossing wartime connection necessitates us dispensing with existing geographical units of historical enquiry. Kenneth J. Ruoff's enlightening examination of Japanese wartime tourism to Manchukuo and China during the 1937-1945 conflict is a case in point. It reveals that war heritage did not wait upon peace to become a powerful source of inter-regional exchange; rather, the Japanese state consciously promoted such tourism to foster a popular and physical engagement of its subjects with their imperial patrimony. While similar tours to Southeast Asian parts of the empire may

\footnotetext{
Japanese literature, Harvard University Press, Cambridge, Massachusetts, 2003. She, however, places her focus on East Asia alone.

${ }^{20}$ M. Baskett, The attractive empire: transnational film culture in imperial Japan, Hawaii University Press, Honolulu, 2008.
} 
well have also developed had the war in the Pacific not turned against the Japanese from late 1942, the scope of Ruoff's study is determined by the reality that it $\operatorname{did}^{21}$

The problems arise when these frames of reference become confining conceptual compartments, which limit our understanding of wartime forces and mechanisms. If any historical event in the history of Asia brought home the reality that life (and death) in one part of the region had becaome linked to places elsewhere and far away, then the war of 1937-1945 was undoubtedly it. For historians to avoid the study of the global interconnections which this conflict produced, because they lure the nation-state or the area studies specialists among them over the border into an alien country, means losing sight of those key transnational actors, those (often newly-formed) supranational contexts, and those intense border-crossing movements and interdependencies which arose from the war and determined the way it unfolded. A narrower historical lens might ensure that the story remains clear and focused. It will still only hint at the myriad ways in which the same story's protagonists fought, imagined, experienced, and determined the outcome of this conflict beyond the geographical boundaries that it so readily altered or obliterated.

That being said, this forum does not seek to make a sacrificial offering of the local, the national or 'the area' at the altar of the pan-Asian and the global. It is hardly its intention to inspire historians to ditch their conceptual baggage and their robes of specialist expertise, so that they can run headlong and unencumbered after wartime connections which take them ever further away from the place where they started. The global frame employed here is not one that aspires to provide global coverage. Rather, we take as our starting point the study of globalization as involving the investigation of transnational phenomena that manifest themselves in 'the movement of people, goods, and knowledge beyond the boundaries of

${ }^{21}$ K. Ruoff, 'Japanese tourism to Mukden, Nanjing and Qufu, 1938-1943'. Japanese Review, vol. 27, 2014, pp. 171-200. 
collectives, as defined by their political or ethnic affiliation' ${ }^{22}$ We furthermore seek to make the (one might say obvious) case that wartime processes that impacted in Asia were 'constructed in [this very] movement between places, sites, and regions. ${ }^{23}$

Most importantly, this forum attempts to provide a rooted understanding of border-crossing wartime connections in which a global perspective is drawn upon to better inform our understanding of place, whether that place be 'the area' of area studies approaches, the nation or the locality. To this end, the articles collected here adopt what might be considered a decidedly non-macro approach to wartime globalization. Each is grounded in the study of a single incident, a single life-story or group of connected life-stories, or a single space, be it a city or nation: the Indian war correspondent who travelled along the 'great crescent' from India down to Java; the female Chinese intellectuals who converged on the suddenly internationalized cities of Wuhan and Chongqing; the Indian medical mission to war-torn China; the national response in the Philippines to the complex transnational ideology of Japanese pan-Asianism; and, finally, the impact of an Italian propaganda mission, with its pageantry of global fascism, on the Japanese home front and on Japan's status internationally.

In all of these studies a global frame means taking the wartime history of the modern-day Asian nation-state out of itself - whether that nation be (in our case) India, China, the Philippines or Japan - in order to then return it to itself, with what is hoped is an enhanced understanding of the way wartime convergences and connections impacted upon it. Indeed, as many of these articles affirm, wartime globalization was a critical historical process which

\footnotetext{
${ }^{22}$ This follows Osterhammel's conceptualisation of transnational history. For the German original, see J. Osterhammel, 'Globalgeschichte', in Geschichte: ein Grundkurs, H.-J. Goertz (ed), $3^{\text {rd }}$ rev. ed., Rowohlt, Reinbek, 2007, p. 596.

${ }^{23}$ I. Hofmeyr in C. A. Bayly et al., 'AHR conversation: on transnational history'. American Historical Review, vol. 111 , no. 5,2006 , p. 1444 .
} 
shaped the future of nascent modern Asian nation-states, a process that could serve ultimately to strengthen rather than weaken them.

\section{The contributions}

In 'The transnational mission of an Indian war correspondent: P. R. S. Mani in Southeast Asia, $1942-45^{\prime}$ provides an insider's view of the border-crossing experiences of Indian troops in British service as they were mobilized and then deployed in Manipur, Burma, and Indonesia. By juxtaposing the official dispatches, private diary entries and later recollections produced by Captain P. R. S. Mani, a British Indian Army Public Relations officer, this article reveals how the production of wartime propaganda and the establishment of transnational wartime communications became open to nationalist subversion and appropriation. Mani embarked on his transnational journey with a mission to move Indian servicemen from the margins in the British public relations machine to the centre. He also used his position as a producer of official military information to further his own patriotic agenda, secretly establishing contact with fellow Indian nationalist in the diaspora, not to mention (eventually) with fellow anti-colonial Asian freedom fighters. After the war, Mani recorded the striking dilemmas which he and his fellow Indian soldiers found themselves in as they became the military enforcers of British interests overseas, while they simultaneously received news of the anti-colonial movement in their homeland. chooses the costly Battle of Surabaya in late 1945 to poignantly illustrate this. Her analysis shows how the under-researched movement of information through Asian wartime journalism impacted on the political landscape of the region, shaping the way its non-European participants viewed their involvement in the conflict in increasingly pan-Asian terms. 
Vivienne Gud, in her contribution 'From Shanghai to Wuhan to San Francisco: patriotic networking among Chinese women intellectuals at the start of the War of Resistance', focuses on the national and eventually global connections spun by educated Chinese women elites. By tracing the way in which several leading female intellectuals organized politicized reading societies and then Women's National Salvation associations at a provincial, a national, and then an international scale, Gud paints a complex picture of the cosmopolitan, cross-party inclusiveness of women's patriotic activism in this crucial period. She ventures beyond more orthodox analyses, which see such activism as the result of top-down guidance by either the Guomindang (GMD) or the Communist Party, and emphasizes the agency of the women themselves. She furthermore connects the spread and vitality of these women's patriotic networks to the forced convergences and rapid internationalization which the war against Japan generated in the retreating Nationalist Government's fortress-capitals of Wuhan and then Chongqing. Gud argues that for patriotic Chinese women intellectuals, the war transformed these cities, not only into whole new metropolises, but into new 'geo-political spaces' of knowledge-making and political engagement that facilitated the increasing interconnection and globalization of their efforts. As these cities morphed into focal points of world-wide attention, the women activists within them were equally lifted onto an international stage. The eyes of a global audience from Singapore to San Francisco became firmly trained on their actions. In turn, such exposure allowed these women activists to muster international support and establish transnational lines of supply which proved critical to wartime China and its anti-Japanese resistance.

That old transnational associations and connections were, indeed, not simply severed with the outbreak of all-out war in China, but strengthened and realigned in manifold ways, is aptly illustrated by $\quad$ article. Entitled "We must send a gift worthy of India and the Congress!" Political humanitarianism in late colonial South Asia', it examines the Indian 
Medical Mission sent to China in 1938 by the Indian National Congress (INC) in support of the Nationalist government. delineates how the organization of this mission gave expression to a new climate of national protest and growing internationalism in India. By dispatching it, the INC joined in a global effort that protested Japanese aggressions. The Congress also drew upon certain pan-Asian ideas that had long circulated in India and had developed in exchange with pan-Asian thinkers situated throughout the region. On the other hand, Framke stresses that the Mission also enabled the INC to appear as if it was performing on an international stage as an independent government of India, unbound by British rule. She therefore argues that the INC thus used this transnational humanitarian mission as a political tool in its arsenal of instruments for anti-colonial emancipation. Like

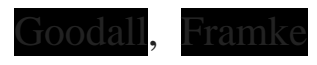
ultimately shows how the forces of wartime globalization meant India's freedom struggle played out on an international stage - with doctors in wartime China.

In 'Re-orienting the Philippines: The KALIBAPI-Party and the application of Japanese PanAsianism, 1942-45', turns our historical lens around, from the transnational back to the national. He explores how Japanese pan-Asianism, an ideology which circulated across Asian borders during World War Two, was shaped and transformed by its encounter with a distinct local context where its target audience did not seem to perceive itself as 'Asian' in the first place. explores, on the one hand, Japan's attempt at enlisting PanAsianism to counter the legacy of the Philippines' extensive exposure to Western colonial influence; and on the other, Filipino resistance to being forcibly subsumed into this new ideological configuration. In order to integrate the Philippines into a Greater East Asia CoProsperity Sphere (GEACPS), Japan devised a strategy intended to drastically alter the local political landscape. It created an organization to spawn a people's movement intended to infuse Filipino society with a new Asian mindset based on 'oriental' rather than 'occidental' values. This organization, the Kapisanan sa Paglilingkod sa Bagong Pilipinas (KALIBAPI), or 
'Association for Service to the New Philippines', replaced all other parties in the archipelago. It was designed to be sensitive to local differences and history, even attempting to ideologically connect itself to the legacies of national Filipino heroes such as the $19^{\text {th }}$ century revolutionary José Rizal. _ـ study thus breaks down the perception of Japanese pan-Asian thought as monolithic, adding a far greater nuance to its study in the occupied territories of wartime Southeast Asia. His article may also be taken as a study of wartime anti-regionalism if not antiglobalization. For concludes that the daunting task of winning over the Filipino people to the transnational project of the GEACPS proved impossible to achieve. For him, the KALIBAPI's failure exemplifies the failure of Japan's pan-Asian ambitions more generally.

The final article in this forum,

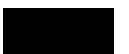
'The spectacle of global fascism: The Italian Blackshirt Mission to Japan's Asian Empire' bridges the Asian and European theatres of war. draws on a wealth of Japanese wartime media which followed and reported on the immensely well-received Italian 'Missione del Partito Nazionale Fascista', which, in the spring of 1938, journeyed through the Japanese Empire, visiting China, Korea, Manchukuo, and Japan itself. Not only was the Mission's voyage turned into a pan-Asian propaganda trip which emphasised Japan's alleged success in uniting Asia; it also contributed to a reassessment of views of Japan in Europe as a 'modern' and powerful international player, reversing a racial discourse in Italy that had previously been critical of Japan's East Asian expansion. Importantly, shows that this new means of conducting diplomacy through cultural means generated a much stronger popular consciousness of the Axis alliance in Japan than is often postulated. On the one hand, the Italian Missione enabled Japanese publicists to globalize their public's conception of the war in China. Simultaneously, the Mission's spectacular visit allowed the Japanese media to localize the Tokyo-Rome-Berlin alliance as something tangible and visceral at a local level with a recognizably pan-Asian face. thus concludes that 1930s Axis diplomacy and ideology can neither be viewed in isolation nor understood by 
simply scrutinizing local-level fascist festivities. It is only through a global lens that the powerful converging and disrupting transnational forces that were at play during the war in Asia reveal themselves.

\section{Conclusion: the legacies of wartime globalization?}

Collectively, the contributions in this forum and the fresh perspectives they offer show the 1937-1945 war in Asia to have driven up the fever curve of a type of globalization which brought into play new border-crossing connections and revived old, just as it destroyed and disrupted others. All these articles, although they focus on different locales across Asia, help us better understand the critical role of war in the intensified transnational movement of information, ideologies, performance, and people. Yet, we may still ask exactly what the longterm historical impact of these sudden, often febrile, and frequently impermanent, wartime mobilities was?

As certain of the articles in this forum begin to show, the answer to this question is complex and far from uniform. In the case of India, the wartime convergences and connections that connected Indian patriots with other Asian freedom fighters generated some degree of panAsian solidarity, which reached its climax with India's independence in 1947, an event celebrated by nationalists across the region. This solidarity might still be perceived to have survived into decolonization with the Bandung Conference in Indonesia in 1955, which Nehru attended. However, the partition of India and Pakistan impacted on India's troubled relationship with another 'Muslim nation', Indonesia, effectively disintegrating the sense of pan-Asian sympathy and solidarity that the Second World War had previously made possible. Moreover, Sino-Indian relations which had experienced a new lease of life through wartime humanitarian links, cooled with the increasing ideological rifts that began to divide the region 
anew as the Cold War progressed, and eventually hit freezing point with the Chinese-Indian border war of 1962. Nevertheless, some longer-term Sino-Indian legacies of wartime globalization were still evident. The fact that the participants in the Indian Medical Mission of 1938 are still evoked by China's communist leaders today as the epitome of exemplary SinoIndian ties, provides evidence of this. ${ }^{24}$

In other cases, the transnational mobilities which the war unleashed came to a swift and even grinding halt once hostilities had formally ceased. Pan-Asian concepts and sentiments that were put to the test in the Philippines, for example, and which had faltered even before Japan's surrender message rang through the archipelago, did not survive much after 1945. The globallyexpansive geo-political spaces that the war had opened up for women intellectuals in China shrank shortly thereafter as well, as China's Civil War and then the 1949 Communist Revolution decimated participation in these formerly inclusive patriotic networks and severed their overseas links.

Finally, if we take a step back, and at last adopt a macro-perspective, we find that the ways in which the war in Asia enabled and forced certain historical actors to globalize their activities were contingent on the direction in which the world, in far off other parts, was at the same time being steered (and more often pushed). For example, the way World War Two unfolded in the region was heavily determined by the arrival, the retreat, the return, and then the final departure of extra-Asian armed forces. When London or Washington decided that these foreign armies should decamp and depart, whole systems of global transportation and communication, along with entire networks of supply went with them

\footnotetext{
${ }^{24}$ Press Trust of India, 'Xi Jinping keeps tradition alive, meets family of Dr Dwarkanath Kotnis', The Indian Express, 19 September 2014, http://indianexpress.com/article/india/india-others/xi-jinping-keeps-tradition-alivemeets-family-of-dr-dwarkanath-kotnis/, [accessed, 1 July 2015].
} 
This reality reminds us once more of the temporal limits of the globalizing processes that originated in, or were accelerated by, world armed conflict. Indeed, by rooting certain transnational convergences and connections in conflicted times, we become as much aware of their erratic and short-lived peculiarities as of their lasting legacies. However, these comparatively short lifespans do not make wartime globalization a less important subject for historical study. Rather, it is hoped that this forum will show the long overdue recognition that wartime globalization demands within the broader study of global and transnational history, not only for Asia but also beyond it. 